\title{
TRUST BREEDS TRUST: HOW TAXPAYERS ARE TREATED
}

Lars Feld and Bruno Frey

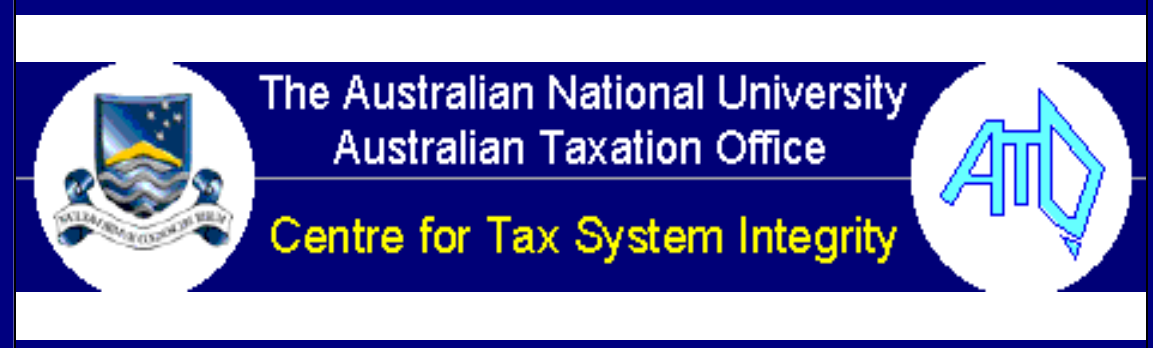

WORKING PAPER No 32

June 2002 


\title{
TRUST BREEDS TRUST: HOW TAXPAYERS ARE TREATED
}

\author{
Lars Feld and Bruno Frey
}

\author{
SERIES' EDITOR \\ Karen Byng
}

Centre for Tax System Integrity

Research School of Social Sciences

Australian National University

Canberra, ACT, 0200

ISBN 0642768315

ISSN 1444-8211

\section{WORKING PAPER No 32}

June 2002 
(C) Centre for Tax System Integrity, Research School of Social Sciences, Australian National University 2002

(C) Commonwealth of Australia 2002

National Library of Australia

Cataloguing-in-Publication data:

Feld, Lars P., 1966- .

Trust breeds trust: How taxpayers are treated.

Bibliography.

ISBN 0642768315.

1. Tax evasion - Switzerland. 2. Tax administration and procedure - Switzerland. 3. Taxpayer compliance -

Switzerland. 4. Taxpayer compliance - Australia. I. Frey, Bruno S. II. Centre for Tax System Integrity. III. Title.

(Series : Working paper (Centre for Tax System Integrity); no. 32).

364.13309494

If you would like to make any comments on this working paper please contact the author directly within 90 days of publication.

\section{Disclaimer}

This article has been written as part of a series of publications issued from the Centre for Tax System Integrity. The views contained in this article are representative of the author only. The publishing of this article does not constitute an endorsement of or any other expression of opinion by the Australian National University or the Commissioner of Taxation of the author's opinion. The Australian National University and the Commissioner of Taxation do not accept any loss, damage or injury howsoever arising that may result from this article. This article does not constitute a public or private ruling within the meaning of the Taxation Administration Act 1953, nor is it an advance opinion of the Commissioner of Taxation. 


\section{THE CENTRE FOR TAX SYSTEM INTEGRITY WORKING PAPERS}

The Centre for Tax System Integrity (CTSI) is a specialised research unit set up as a partnership between the Australian National University (ANU) and the Australian Taxation Office (Tax Office) to extend our understanding of how and why cooperation and contestation occur within the tax system.

This series of working papers is designed to bring the research of the Centre for Tax System Integrity to as wide an audience as possible and to promote discussion among researchers, academics and practitioners both nationally and internationally on taxation compliance.

The working papers are selected with three criteria in mind: (1) to share knowledge, experience and preliminary findings from research projects; (2) to provide an outlet for policy focused research and discussion papers; and (3) to give ready access to previews of papers destined for publication in academic journals, edited collections, or research monographs.

Series' Editor:

Karen Byng 


\begin{abstract}
Tax compliance has been studied in economics by analysing the individual decision of a representative person between paying and evading taxes. A neglected aspect of tax compliance is the interaction of taxpayers and tax authorities. The relationship between the two actors can be understood as an implicit or 'psychological' contract. Studies on tax evasion in Switzerland show that the more strongly the political participation rights are developed, the more important the contract is, and the higher tax morale is. In this paper, empirical evidence based on a survey of tax authorities of the twenty-six Swiss states (cantons) is presented, indicating that the differences in the treatment of taxpayers by tax authorities can be explained by differences in political participation rights as well.
\end{abstract}




\title{
Trust breeds trust: How taxpayers are treated
}

\author{
Lars P. Feld ${ }^{1}$ and Bruno S. Frey ${ }^{2}$
}

\section{A neglected aspect}

Tax compliance has been studied in economics by analysing the individual decision of a representative person between paying and evading taxes. The literature has been shaped by the path-breaking contribution by Allingham and Sandmo (1972), with the consequent extensions by, among others, Kolm (1973) and Srinivasan (1973). They are all specific, and particularly important, applications of Becker's (1968) economic theory of crime. The present state of the art has been summarised and critically discussed by Andreoni, Erard and Feinstein (1998) in their extensive survey on 'Tax Compliance'.

The approach is, however, faced with various problems, even when the models are extended to include endogenous labour supply, or to consider the repeated nature of the reporting decision: '... complex and confounding effects are not limited to complicated models - even within the simple approach ... we cannot predict the effects of all policy parameters. Moreover, when such predictions can be obtained, they often depend on the thin reed of the third derivative of utility functions and on inelastic labor supply' (Andreoni et al., 1998, p. 824). In particular, an increase in the tax rate has a theoretically ambiguous effect in most models (but see Yitzhaki, 1974), yet both experimental, as well as econometric, research consistently finds that higher tax rates are associated with greater evasion. Even more importantly, an increase in fines discourages evasion. ${ }^{4}$ This corresponds to the thrust of the economics of crime and offers an important avenue for tax policy. But this effect becomes theoretically ambiguous with elastic labour supply.

\footnotetext{
${ }^{1}$. University of Marburg, Germany.

2. University of Zurich, Switzerland.

${ }^{3}$. Other surveys on the subject are, for example Pommerehne (1985); Hessing, Kinsey, Elffers \& Weigel (1988); Roth, Scholz \& Witte (1989); Pyle (1990); Cowell (1990); or Slemrod (1992). The extensive literature on the hidden, shadow or underground economy is closely related and starts with the same theoretical premises. See for example Tanzi (1982); Frey \& Pommerehne (1984); Gaertner \& Wenig (1985); Feige (1989); Pozo (1996); Schneider \& Enste (2000); or Frey \& Schneider (2000).

${ }^{4}$. In particular, an increased probability of detection is more effective in reducing tax evasion than higher punishment. This point has been mentioned to us by a referee.
} 
Empirically, studies find that expected punishment is rarely statistically significant and, if it is, the effect is of quite a small magnitude. ${ }^{5}$

A major puzzle is that most theoretical approaches greatly overpredict non-compliance (Andreoni et al., 1998, p. 855). In their article with the revealing title 'Why do people pay taxes?' Alm, McClelland and Schulze (1992, p. 22) state: 'A purely economic analysis of the evasion gamble implies that most individuals would evade if they are 'rational', because it is unlikely that cheaters will be caught and penalised'. Indeed, under the prevailing magnitudes obtained in the United States for the probability of being caught and the size of the fines imposed, individuals optimally declare no income. Arrow-Pratt measures of risk aversion of more than thirty must exist in order to account for the present compliance rate, but existing field evidence suggests a range of between one and two. The same has been found for Switzerland. ${ }^{6}$ One of the solutions to this puzzle or anomaly has been to accept the existence of an intrinsic motivation to pay taxes, which has sometimes been called 'tax morale'.

However, most studies treat 'tax morale' as a black box without discussing or even considering how it might arise or how it might be maintained. It is usually perceived as being part of the meta-preferences of taxpayers and used as the remainder in the analysis capturing unknown influences to tax evasion. The more interesting question then is which factors shape the emergence and maintenance of tax morale. Studies by Pommerehne and Weck-Hannemann (1996), and Frey (1997a) show that the lower the tax evasion at the Swiss cantonal level is, the stronger political participation rights in the sense of direct

\footnotetext{
5. For laboratory experiments, see Alm, Jackson \& McKee (1992); for statistical studies see Witte \& Woodbury (1985); Dubin \& Wilde (1988); Beron, Tauchen \& Witte (1992); Dubin, Graetz \& Wilde (1990) for American data; and Pommerehne \& Frey (1992) for Swiss data.

6. For the U.S., see Graetz \& Wilde (1985); Skinner \& Slemrod (1985); or Alm et al. (1992b); for Switzerland see Pommerehne \& Frey (1992).

7. Thus, for example, Graetz \& Wilde conclude on the basis of the Internal Revenue Service's Taxpayer Compliance Maintenance Programme (1985, p. 358) that '... the high compliance rate can only be explained in a satisfactory way either by taxpayer's (...) commitment to the responsibilities of citizenship and respect for the law or lack of opportunity for tax evasion'. Accordingly, the observed falling tax compliance has been attributed to the erosion of tax ethics by Graetz, Reinganum \& Wilde (1986) and many other authors (for example see Schwartz \& Orleans, 1967; Lewis, 1982; Roth, Scholz \& Witte, 1989; Pyle, 1990; Slemrod, 1992).
} 
democratic decision-making like referenda and initiatives are developed. Tax morale appears to be higher where taxpayers can influence tax laws and tax rates, and also the rules of the tax game in general. Taxpayers perceive their civic duty more strongly if they are directly involved in political decisions of content instead of solely electing representatives on a regular basis.

This paper looks at tax compliance from a different perspective. It therewith attempts to overcome some of the shortcomings mentioned and to add to the explanation of the negative relationship between tax evasion and political participation rights. It focuses on how the tax authorities treat taxpayers. The relationship between the two actors is taken to involve an implicit or 'psychological' contract. The more strongly the political participation rights are developed, the more important this contract is, and the higher tax morale is. The existence and survival of this tax contract requires certain behaviour on the part of the two parties concerned. In particular, the tax authorities must acknowledge and support the contract with the taxpayers by acting in a respectful way towards them, but also by preventing honest taxpayers from being exploited in the process. The need to act in such a way is stronger in democracies with institutions of popular initiatives and referenda than in purely representative democracies. Thus, the paper considers some completely different instruments of tax policy compared to the more traditional analysis.

Our empirical analysis employs a unique data set of tax authorities' behaviour in Switzerland, allowing cross-section estimates of the twenty-six cantons with widely varying tax systems and tax rates. ${ }^{8}$ The remainder of the paper is organised as follows. Section II discusses the theoretical background. Section III presents the data collected by us and empirical evidence on the relationship between the respectful treatment of taxpayers by tax authorities and the extent of voter participation rights. In Section $I V$, evidence on differences between the punishment of basic rule violations in direct and representative cantons is discussed, while Section $V$ contains some empirical results on the different treatment of minor violations of the tax code by the tax authorities in direct and representative democratic cantons. A synthesis is offered in Section VI.

\footnotetext{
${ }^{8}$. We thus also respond to the 'need' identified by Andreoni et al. (1998, p. 856) 'for more empirical and institutional research within jurisdictions outside the U.S.'.
} 


\section{Theoretical background}

The relationship between taxpayers and tax authorities can be modelled as an implicit or relational contract (for example Akerlof, 1982). It thus involves strong emotional ties and loyalties, and goes well beyond transactional exchanges (see for example Williamson, 1985). Social psychologists (Schein 1965; Rousseau \& McLean Parks, 1993) have been using this concept for a long time, calling it a 'psychological' contract to set it clearly apart from formal contracts, which are obeyed because the parties respond to the explicit and material sanction previously agreed upon. Psychological contracts have been successfully used to analyse relationships within the firm (for example Osterloh \& Frey, 2000).

A psychological contract aptly captures the relationship between taxpayers and the tax authority. As has been pointed out above, careful empirical research has established that it is more difficult to account for tax compliance in terms of expected punishment. Rather, the payment of taxes is, as Levi (1988) calls it, a 'quasi-voluntary' act, which is not solely undertaken because one fears explicit governmental sanctions. Alm et al. (1992b, p. 23) refer to an extensive economic literature', suggesting that individuals pay taxes voluntarily'. This does not mean, of course, that threats of explicit punishment play no role, but it draws attention to other aspects of taxpayers' compliance decisions than those normally considered in the economics literature.

Many conditions determine the extent to which a psychological contract between taxpayers and tax authorities exists. An important element is certainly tradition. But when one asks how such a tradition may have arisen, the amount of trust in the citizens implied by the constitution is crucial. The more strongly a constitution extends participation rights to its citizens, the more likely such a psychological tax contract is to emerge. ${ }^{10}$ A democracy is an institution in which the citizens are trusted, in the sense that they are given the right to choose their government in free elections. (Semi-)direct democracies, as they mainly exist in some American states and at all government levels in Switzerland, go a decisive step

\footnotetext{
${ }^{9}$. For example Spicer \& Lundstedt (1976); Kim \& Walker (1984); Isaac, Walker \& Thomas (1984); Isaac, McCue \& Plott (1985); Falkinger (1991); Cullis \& Lewis (1997).

10. See more fully Frey (1997a). Related works comprise, for example Elster (1989); Etzioni (1988); Fukuyama (1995); Gambetta (1988); Kelman (1992); Kramer \& Tyler (1995); Mansbridge (1994); Putnam (1993); Sunstein (1990); Taylor (1987); Wilson (1993).
} 
further. They trust their citizens to be able to take reasonable decisions on matters of content. ${ }^{11}$ As a consequence, the psychological tax contract, and thus tax morale, is higher, the more developed the institutions of direct citizen participation are. This has been empirically shown using an econometric cross section/time series analysis of twenty-five Swiss cantons for 1965, 1970 and 1978 (Pommerehne \& Weck-Hannemann, 1996; Frey, 1997a). ${ }^{12}$ In these studies, aggregate tax evasion at the cantonal level is explained by marginal tax rates, income, the probability of being detected, fines, some sociodemographic indicators like the share of pensioners and a variable capturing the intensity of direct voter participation. Tax evasion is Sfr (Swiss franc) 1500 per taxpayer lower in direct democratic cantons than in others.

The breach of a psychological contract puts the reciprocal good faith into question. In this case, empirical evidence (Robinson, Kratz \& Rousseau, 1994) clearly indicates that the parties to the contract perceive that the relationship is transformed into a purely extrinsically motivated contract. Citizens' tax morale is crowded out ${ }^{13}$, and individuals take a purely rationalistic attitude towards tax payment. If the breach of contract results in a complete crowding out of tax morale, the citizens behave exactly as predicted by the conventional theory discussed above. Essentially, they refuse to pay taxes (at least under the probability of being audited and the size of punishment currently administered in countries such as the U.S. or Switzerland). It follows that particular care must be taken to maintain and protect the psychological tax contract in a democracy with more extensive formal participation rights. If the taxpayers feel that the tax authority does not honour the psychological contract, the resulting change in behaviour towards a purely rationalist attitude is larger than in a purely representative democracy. In the extreme, in a political system without participation rights, the psychological contract does not exist at all, and thus there is no scope for any crowding out effect. Under this condition, the tax authority does not have to treat the citizens respectfully, but can rely solely on deterrence.

\footnotetext{
${ }^{11}$. Facts are provided in Butler \& Ranney (1994). Analytical discussions are provided in, for example Budge (1996); Cronin (1989); or Frey (1994). Kirchgässner, Feld \& Savioz (1999) give an extensive account of the consequences of direct democracy on economic and social variables.

${ }^{12}$. Switzerland consists of 26 cantons. The 26th canton, the canton of Jura, was established in 1977 by secession from the canton of Berne. Since the data used by Pommerehne \& Weck-Hannemann (1996) and Frey (1997a) cover the period up to 1978, they could not include data on the canton of Jura in the data set.
} 


\section{The respectful treatment of taxpayers}

To maintain the psychological tax contract, the tax authority must take positive actions to support it, and negative actions to prevent breach of contract. The basis of any contractual relationship that relies on trust is the prior belief that the partner in the contract behaves honestly. The same applies to the psychological contract between tax authorities and taxpayers: tax authorities suppose that taxpayers will honestly report their true income on the tax declaration. On the other hand, taxpayers expect to be treated respectfully, as if they are honestly reporting their true income. A strategy of tax authorities to suspect taxpayers of being evaders right from the beginning would undermine the psychological contract between taxpayers and tax authorities. Treating citizens respectfully can be expected to be more pronounced in polities with constitutional provisions for direct voter participation, like referenda and initiatives, because both taxpayers and tax authorities know that voters support public policies, which clearly sustain the public good. In such systems of direct democracy, taxpayers know that the public services they consume are worth the taxes they pay. Taxpayers therefore feel obliged to pay their taxes. Tax authorities know that voters could change tax laws in the political process. Citizens thus have much better possibilities of expressing their discontent with the tax policy than a quiet and secret violation of the psychological contract with tax authorities. Even if some groups of voters lose in a referendum, they comply with tax laws as long as they perceive political outcomes to be the results of fair procedures. This aspect should be less pronounced in representative democracies where the influence of taxpayers on political outcomes is less direct. These considerations lead us to the following propositions for direct democracies:

(1) More trust is placed in taxpayers. In particular, when tax returns contain a mistake, the tax officers do not automatically suspect any intention of cheating, but give the contract partner the benefit of the doubt;

(2) Taxpayers are more respectfully treated as partners in a contract rather than as inferiors in a hierarchical and bureaucratic relationship;

\footnotetext{
${ }^{13}$. Crowding theory is more fully developed in Frey (1997b). The experimental and field evidence, including econometric studies, is summarised in Frey \& Jegen (2000).
} 

authorities and taxpayers exists, in order not to undermine the relationship of mutual trust by distrustful action.

These actions and the corresponding empirically testable propositions should not be understood in any absolute sense. Rather, it is proposed that they are more pronounced, the more extensive the direct participation rights of the citizens are. Differences in the administration of taxes between the cantons are thus expected to be the result of constitutional differences. The cantonal constitutions of Switzerland offer different possibilities for direct voter participation in political decision making. In some cantons, only an obligatory constitutional referendum is laid down in the constitution. In other cantons, all kinds of statutory and constitutional referenda and initiatives are possible. Moreover, requirements on collecting signatures for initiatives and optional (statutory and constitutional) referenda, as well as the number of days allowed to collect them, vary between cantons. The extent to which voters may directly participate in the different cantons is measured by an index, compiled by Stutzer (1999), that varies on a continuum from 1 to $6 .^{14}$

In order to investigate the relationship between taxpayers and tax authorities, we sent out a survey to the tax authorities of the twenty-six Swiss cantons. ${ }^{15}$ The survey asked detailed questions on the legal background of tax evasion, like the use and size of fines, whether an explicit link of tax payments to the provision of public services is established, the

\footnotetext{
${ }^{14}$. The different signature requirements and numbers of days to collect them in the case of (constitutional and statutory) initiatives and optional referenda, as well as the existence of a mandatory statutory referendum are translated in an index that has the value of ' 6 ' in the case of cantons with strongest political participation rights and ' 1 ' in the case of cantons with weak political participation rights. See Stutzer (1999) for details on the computation of the index. Frey \& Stutzer (2000) have successfully used this index of direct democracy to account for differences in subjective well-being between cantons.

${ }^{15}$. It should be noted that the Swiss cantons have the basic power to tax personal and corporate income, while the local jurisdictions levy a surcharge on cantonal income taxes. Cantons can, with few restrictions, set tax rates and define tax bases. Both lead to a strong variation in (effective) tax rates among cantons and among local jurisdictions. The federal level mainly raises indirect taxes, but also a highly progressive federal income tax. Tax evasion laws form part of the legal power of the Swiss cantons as well. With the exception of interest and dividend incomes, which are collected at the federal level at source, Swiss taxpayers do not pay any other withholding taxes. They have to report their incomes regularly (annually or biannually) in a selfassessment procedure. In addition, firms have less duties to publish their accounts to the government than in other OECD countries. The small extent of withholding taxes increases the ability to evade taxes while
} 
perceived feedback effect of tax evasion on the level of public services, the intensity of control by tax authorities, the existence of tax amnesties, whether the tax register is published in a jurisdiction and the extent of tax indexation. Finally, the survey includes questions on the treatment of taxpayers by tax authorities in day-to-day audits, in particular when a taxpayer is suspected of not declaring his or her true taxable income. These questions go into considerable detail. The legally oriented part of the questionnaire, for example, stresses the differences according to how severe the tax evasion is, the punishment in case of tax fraud, the period considered and so on. ${ }^{16}$ Similarly detailed questions apply to other parts of the survey. ${ }^{17}$

The way taxpayers are treated by tax authorities reveals interesting differences between the Swiss cantons. Only 58\% of Swiss cantonal tax authorities believe that mistakes in reported incomes are, on average, in favour of taxpayers. Thirty-one per cent believe that mistakes are neither to the advantage nor to the disadvantage of taxpayers, and $12 \%$ believe that mistakes are to the disadvantage of taxpayers. This evidence indicates the lack of general distrust towards taxpayers.

If a taxpayer does not report his or her true taxable income, tax authorities can contact this person in several ways. Fifty-four per cent of the cantons call this person on the phone and ask how the mistake(s) occurred in the declaration of income and what explanation the taxpayer has. ${ }^{18}$ All of the cantons send a letter to the taxpayer, half of them with a standard formulation. Nearly $85 \%$ ask the taxpayer to visit the tax administration office, but only half of the cantons mention the possibility of punishment. Thus, tax authorities rarely adopt the strategy of explicit deterrence, but rather seek to gain additional information.

restrictions on it by third party information are smaller than in other countries. See Feld (2000) for a more detailed description of the Swiss fiscal system.

16. The questionnaire was sent to the chief administrators of the cantonal tax authorities. In addition, we asked for a specific contact in the authority if there were any clarifying questions. These people usually belonged to the senior administrative body and in most cases had a university degree as a lawyer. Casual discussions on the phone revealed that some chief administrators responded to the questionnaire personally.

17. An English translation of the questionnaire can be obtained from the authors upon request.

18. In the questionnaire, the two dimensions of tax evasion as reporting of too low a gross income and as overstating cost deductions were treated as one. We asked the opposite however, namely, whether the tax authorities equally treated reporting too high an income due to mistakes in the addition of figures and forgetting to deduct usual components. 
Ninety-six per cent of the cantonal tax authorities correct reported incomes that are too high, that is reduce taxable incomes in case taxpayers commit mistakes that are to their disadvantage. Twenty-seven per cent of the cantonal tax authorities correct reported taxable income even if they fail to profit from legal tax savings.

Table 1: Respectful Treatment of Taxpayers in Direct and Representative Democratic Cantons

\begin{tabular}{|c|c|c|c|c|c|}
\hline Dependent Variables & Constant & $\begin{array}{c}\text { Index of } \\
\text { Direct } \\
\text { Democracy }\end{array}$ & $\begin{array}{l}\text { Regional } \\
\text { Dummy }\end{array}$ & Population & $R^{2}$ \\
\hline $\begin{array}{l}\text { Mistakes in favour of } \\
\text { taxpayers }\end{array}$ & 1.961 & $\begin{array}{c}-0.406^{*} \\
(-2.30)\end{array}$ & $\begin{array}{l}-0.613 \\
(-1.44)\end{array}$ & $\begin{array}{l}0.001 \\
(0.90)\end{array}$ & 0.142 \\
\hline Invitation to a Tax Audit & 4.301 & $\begin{array}{c}-0.694(*) \\
(-1.77)\end{array}$ & $\begin{array}{l}-1.287 \\
(-1.07)\end{array}$ & $\begin{array}{l}0.000 \\
(0.21)\end{array}$ & 0.158 \\
\hline $\begin{array}{l}\text { Opening Up the Tax } \\
\text { Register }\end{array}$ & 1.328 & $\begin{array}{l}-1.033^{*} \\
(-1.99)\end{array}$ & $\begin{array}{l}0.190 \\
(0.15)\end{array}$ & $\begin{array}{l}0.002 \\
(1.29)\end{array}$ & 0.289 \\
\hline
\end{tabular}

The variable 'mistakes in favour of taxpayers' is scaled ' 1 ' if the respondent thinks that mistakes are in favour, ' -1 ' if he/she thinks they are to the disadvantage and zero otherwise; the variables 'invitation ...' and 'opening up ...' are dummy variables with a value of ' 1 ' if people are invited to the tax authority for a tax audit or the tax register is opened up, respectively, or zero otherwise. The estimation method is Maximum Likelihood using the QML (Huber/ White) standard errors and covariances. The numbers in parentheses are the t-statistics of the estimated parameters. ' $\left({ }^{*}\right)$ ', ' $*$ ', or ' $* *$ ' denotes significance at the 90,95 , or 99 per cent confidence level, respectively. McFadden's $\mathrm{R}^{2}$ are reported in the last column.

There are remarkable differences in the treatment of taxpayers between direct and representative democratic cantons. The results are reported in Table 1. Tax authorities in cantons with stronger elements of direct democracy show less distrust towards taxpayers that commit mistakes in their declarations of taxable income. More directly democratic cantons have a significantly lower probability of automatically suspecting that mistakes are generally in favour of taxpayers than more representative democratic cantons. ${ }^{19}$ This evidence supports Proposition 1.

\footnotetext{
19. The empirical tests are performed employing the GLS regression method for continuous variables, and using the square root of the cantonal population in the case of average variables and the inverse of the square root of the cantonal population in the case of sums as a weight. If the dependent variable is a discrete variable (binary or ordered) Logit estimates are used. In all cases, the robustness of the tests is checked by additionally introducing a dummy variable, which takes the value one if the canton is a French or Italian speaking canton and zero otherwise. This is done to check whether observed differences in tax authorities' treatment of taxpayers between more and less directly democratic cantons simply reflect the differences
} 
Taxpayers declaring a taxable income that is too low have a lower probability of being invited to the tax administration for a formal tax audit in more directly democratic than in less directly democratic cantons. This result supports the notion that taxpayers declaring a lower than the true taxable income are more respectfully treated if a psychological contract exists, something that is more probable in jurisdictions with higher voter participation rights. This finding is consistent with Proposition 2.

Does the intensity of control vary among cantons with different constitutional systems? The intensity of control, as measured by the number of tax investigators to the number of tax evasion cases varies from 0.02 to 0.78 , with a mean of 0.30 and a standard deviation of 0.19 . Interestingly enough, there are no differences in the probability of detection of tax evasion between more and less directly democratic cantons, whether this control intensity is measured by the number of tax commissioners per taxpayer, or the number of tax commissioners per average number of tax evasion or fraud proceedings during recent years. However, control intensity differs with respect to the possibilities for self-control of the taxpayers by opening up the tax register. The probability that the tax register is opened up is significantly lower in direct democratic cantons (when the differences between the language regions are controlled for). ${ }^{20}$ This result is consistent with Proposition 3.

\section{Violation of basic rules}

As mentioned above, a psychological tax contract must be maintained by positive actions revealing a respectful treatment of taxpayers, but also by negative actions in order to prevent the breach of the contract. A basic trust of tax authorities with respect to the honesty of taxpayers and a respectful treatment of taxpayers by the tax authorities must thus be accompanied by incentives for taxpayers to observe the rules of the game. If honest taxpayers reporting their true incomes realise that other persons report too little income, they may feel annoyed by those people neglecting the basic rules of citizen duty. These considerations particularly hold in polities with direct democracy, since those voters who

between the culturally different language areas. In addition, the size of the cantonal population is introduced in the model.

${ }^{20}$. Opening up the tax register means that citizens at the cantonal or local level can have insight into the tax register. It is publicly available in the tax administration to the citizens of a jurisdiction in some cantons. 
are frustrated about the uncooperative behaviour of a number of their fellow citizens will express this discontent strongly at the polls. This leads us to Proposition 4:

(4) Violations of basic rules of the tax code are punished more severely in directly democratic cantons in order to make clear that the psychological contract is at stake; ${ }^{21}$

Our survey contains several questions about the treatment of taxpayers by the tax authorities with respect to the quality of personal interactions. The results are reported in the upper part of Table 2. Taxpayers who do not submit their tax declarations are fined more heavily in more directly democratic cantons than in less directly democratic ones. Such persons do not comply with the basic obligation of taxpaying and are more severely fined in order to deter them from showing no interest in maintaining the public good. On the other hand, more directly democratic cantons have a higher probability than less directly democratic cantons of offering the same legal objection possibilities to those people with no declaration of taxable income as those with self-declaration of incomes. This again indicates that even taxpayers who do not submit a declaration of their taxable income are treated more respectfully in more directly democratic jurisdictions than in less directly democratic ones.

\footnotetext{
${ }^{21}$. Experimental research has clearly established that the willingness to contribute to a public good breaks down when people feel taken advantage of. See Feld, Hart \& Ostmann (1996). In the case of taxation, see Spicer (1988). In a similar context, Lewis (1982) emphasises that perceived inequity may be a reason for tax evasion. The severe punishment of violations of basic rules may be a means to reduce perceived inequity.
} 
Table 2: The Treatment of Violations of the Tax Code in Direct and Representative Democratic Cantons

\begin{tabular}{lccccc}
\hline \multicolumn{1}{c}{$\begin{array}{c}\text { Index of } \\
\text { Direct } \\
\text { Dependent Variables }\end{array}$} & Constant & $\begin{array}{c}\text { Regional } \\
\text { Democracy }\end{array}$ & Dummy & Population & $R^{2}$ \\
\hline $\begin{array}{l}\text { Fine for Lack of } \\
\text { Submission of Tax }\end{array}$ & -4216.89 & $\begin{array}{c}1942.74^{*} \\
(2.70)\end{array}$ & $\begin{array}{c}3733.31\left(^{*}\right) \\
(2.00)\end{array}$ & $\begin{array}{c}-0.881 \\
(0.17)\end{array}$ & 0.378 \\
$\begin{array}{l}\text { Declaration } \\
\text { Legal Objection }\end{array}$ & -9.183 & $1.949^{*}$ & 2.582 & 0.001 & 0.300 \\
$\begin{array}{l}\text { Possibilities in the Case } \\
\text { of No Declaration }\end{array}$ & & $(2.25)$ & $(1.38)$ & $(0.86)$ & \\
Maximum Fines & 653.87 & $-79.144\left(^{*}\right)$ & 53.424 & -0.011 & 0.122 \\
& & $(-1.85)$ & $(0.61)$ & $(-0.17)$ & \\
Fines in the Case of & 52.425 & $-8.969\left(^{*}\right)$ & -18.023 & 0.030 & 0.251 \\
Self-Denunciation & & $(-1.80)$ & $(-1.33)$ & $(1.02)$ & \\
\hline
\end{tabular}

The variables 'maximum fines' and 'fines in the case of self-denunciation' are continuous variables indicating the multiple of the amount evaded that has to be paid as a fine, while the variable 'fine for lack of submission of tax declaration' is the absolute amount in Sfr. The variable 'legal objection possibilities ...' is a dummy variable with a value of ' 1 ' if legal objection possibilities in the case of no declaration are the same as in the case of self declaration with tax evasion, and zero otherwise. With the exception of legal objection possibilities in which Maximum Likelihood estimates are reported again using QML (Huber/ White) standard errors and covariances, the remaining estimates are derived by GLS. The numbers in parentheses are the t-statistics of the estimated parameters. '(*)', '*', or '**' denotes significance at the 90,95 , or 99 percent confidence level, respectively. The last column reports adjusted $\mathrm{R}^{2}$ (corrected by the degrees of freedom) and in the case of legal objection possibilities McFadden's $\mathrm{R}^{2}$.

\section{Minor violations of the tax code}

Nobody is perfect, and to cheat a little bit on taxes is a common and minor human weakness, and should be considered as such. Such minor violations should not be interpreted as an action intended to breach the psychological contract. An exaggerated punishment of minor violations of the tax code is interpreted as an inadequate reaction by the public authorities. The tolerance for such minor human weaknesses is indeed reflected in political systems with direct voter participation in the political process. Taxpayers vote for low punishment of minor violations of the tax code, acknowledging that nobody is perfect and that everyone is liable to commit small mistakes. This reasoning leads us to Proposition (5): 
(5) Minor violations of the tax code are punished less severely in direct democratic cantons.

The Swiss cantonal tax authorities' answers reveal quite a strong variation in their treatment of tax evasion. For example, the minimum fine in the case of tax evasion varies between zero and $100 \%$ of true tax payment, with a mean of $28 \%$ and a standard deviation of 21 , while the maximum rate varies from $100 \%$ to $1000 \%$ of the true tax payment, with a mean of $344 \%$ and a standard deviation of 163 . The fines in the case of tax fraud vary accordingly. The corresponding estimates are reported in the lower part of Table 2. With respect to fines, we obtain significantly lower maximum fines for tax evasion in more direct democratic cantons (while French and Italian speaking cantons do not have significantly different maximum fines). In the case of self-denunciation, the fines are lower in cantons with more voter participation possibilities. All in all, tax evasion tends to be less heavily fined in direct democratic cantons. These tests thus provide (limited) empirical support for Proposition 5.

\section{A synthesis}

Tax compliance is not simply the result of opportunities to evade tax and the deterrence and prevention strategies of tax authorities. Tax compliance to a considerable extent has to be attributed to tax morale of taxpayers. If that were not so, given the current deterrence measures in most countries, in particular the U.S. and Switzerland, a rational taxpayer would not have any incentive to abstain from tax evasion. Tax morale, on the other hand, is not simply the result of one's upbringing. It depends on the interaction of taxpayers with tax authorities, on the legal framework, and on the constitutional environment. In this paper, the interaction of taxpayers with tax authorities is analysed and linked to constitutional differences between Swiss cantons, in particular the opportunities the cantonal constitutions offer the voters to directly participate in referenda and initiatives.

On the basis of the political process via results of a survey among the twenty-six cantonal tax authorities, it turns out that the tax authorities of cantons with more direct participation rights, compared to cantons with less direct democracy, are less suspicious if taxpayers 
report incomes that are too low. They treat taxpayers more respectfully. Persons who do not submit their tax declarations, indicating that they do not comply with the basic rules of the game, are more heavily fined in direct democratic cantons. Tax evasion is fined with lower rates. Thus, in direct democracy, minor violations of the tax code are punished less severely than major violations. All in all, respectful treatment and trust are accompanied by generosity in the case of minor human weaknesses, but strong deterrence if the psychological tax contract is at stake. The analysis suggests that there is an implicit psychological contract between taxpayers and tax authorities in Switzerland. This holds in particular if voters are directly involved in political decision-making. The psychological contract is based on a relationship of trust. 


\section{REFERENCES}

Akerlof, G. A. (1982). Labor contracts as partial gift exchange. Quarterly Journal of Economics, 84, 488-500.

Allingham, M. G., \& Sandmo A. (1972). Income tax evasion: A theoretical analysis. Journal of Public Economics, 1, 323-338.

Alm, J., Jackson, B. R., \& McKee, M. (1992a). Estimating the determinants of taxpayer compliance with experimental data. National Tax Journal, 45, 107-114.

Alm, J., McClelland, G. H., \& Schulze, W. D. (1992b) Why do people pay taxes? Journal of Public Economics, 48, 21-38.

Andreoni, J., Erard, B., \& Feinstein, J. (1998). Tax compliance. Journal of Economic Literature, 36, 818-860.

Becker, G. S. (1968). Crime and punishment: An economic approach. Journal of Political Economy, 76, 169-217.

Beron, K. J., Tauchen, H. V., \& Witte, A. D. (1992). The effect of audits and socioeconomic variables on compliance. In J. Slemrod (Ed.), Why People Pay Taxes: Tax Compliance and Enforcement (pp. 67-89). Ann Arbor: University of Michigan Press.

Budge, I. (1996). The New Challenge of Direct Democracy. Cambridge: Polity Press.

Butler, D., \& Ranney, A. (Eds.). (1994). Referendums Around the World: The Growing Use of Direct Democracy. Basingstoke: MacMillan.

Cowell, F. A. (1990). Cheating the Government: The Economics of Evasion. Cambridge: MIT Press. 
Cronin, T. E. (1989). Direct Democracy: The Politics of Initiative, Referendum, and Recall. Cambridge: Harvard University Press.

Cullis, J. G., \& Lewis, A. (1997). Why people pay taxes: From a conventional economic model to a model of social convention. Journal of Economic Psychology, 18, 305-321.

Dubin, J. A., \& Wilde, L. L. (1988). An empirical analysis of federal income tax auditing and compliance. National Tax Journal, 41, 61-74.

Dubin, J. A., Graetz, M. J., \& Wilde, L. L. (1990). The effect of audit rates on the federal individual income tax, 1977-1986. National Tax Journal, 43, 395-409.

Elster, J. (1989). Social norms and economic theory. Journal of Economic Perspectives, 3(4), 99-119.

Etzioni, A. (1988). The Moral Dimension. Toward a New Economics. New York: Free Press.

Falkinger, J. (1991). On optimal public good provision with tax evasion. Journal of Public Economics, 45, 127-133.

Feige, E. L. (1989). The Underground Economies: Tax Evasion and Information Distortion. Cambridge: Cambridge University Press.

Feld, L. P. (2000). Steuerwettbewerb und seine Auswirkungen auf Allokation und Distribution: Eine empirische Analyse für die Schweiz. Tübingen: Mohr (Siebeck).

Feld, L. P., Hart, A., \& Ostmann, A. (1996). Response models to sanctioning regimes for common pool resources: A panel data approach. Unpublished Manuscript, University of St. Gallen. 
Frey, B. S. (1994). Direct democracy: Politico-economic lessons from Swiss experience. American Economic Review, Papers and Proceedings, 84(2), 338-342.

Frey, B. S. (1997a). A constitution for knaves crowds out civic virtues. Economic Journal, 107, 1043-1053.

Frey, B. S. (1997b). Not Just for The Money. An Economic Theory of Personal Motivation. Cheltenham: Edward Elgar.

Frey, B. S., \& Jegen, R. (2000). Motivation crowding theory: A survey of empirical evidence. Journal of Economic Surveys: forthcoming.

Frey, B. S., \& Pommerehne, W. W. (1984). The hidden economy: State and prospect for measurement. Review of Income and Wealth, 30, 1-23.

Frey, B. S., \& Schneider, F. (2000). Informal and underground economy. Forthcoming in: Smelser, N. J., \& Baltes, P. B. (Eds.), International Encyclopedia of the Social and Behavioral Sciences. Oxford: Elsevier.

Frey, B. S., and Stutzer, A. (2000). Happiness, economy, and institutions. Forthcoming in: Economic Journal.

Fukuyama, F. (1995). Trust: The Social Virtues and the Creation of Property. New York: Free Press.

Gaertner, W., \& Wenig, A. (Eds.). (1985). The Economics of the Shadow Economy. Berlin: Springer.

Gambetta, D. (Ed.). (1988). Trust: Making and Breaking Cooperative Relations. Cambridge: Cambridge University Press. 
Graetz, M. J., \& Wilde, L. L. (1985). The economics of tax compliance: Facts and fantasy. National Tax Journal, 38, 355-363.

Graetz, M. J., Reinganum, J. F., \& Wilde, L. L. (1986). The tax compliance game: Toward an interactive theory of law enforcement. Journal of Law, Economics, and Organization, 2, $1-32$.

Hessing, D. J., Kinsey, K. A., Elffers, H., \& Weigel, R. H. (1988). Tax evasion research: Measurement strategies and theoretical models. In W. Van Raaij, G. van Veldhoven,. \& K. Wärneryd (Eds.), Handbook of Economic Psychology (pp. 515-537). Dordrecht: Kluwer.

Isaac, R. M., McCue, K., \& Plott, C. (1985). Public goods provision in an experimental environment. Journal of Public Economics, 26, 51-74.

Isaac, R. M., Walker, J. M., \& Thomas, S. H. (1984). Divergent evidence on free riding: An experimental examination of possible explanations. Public Choice, 43, 113-149.

Kelman, S. (1992). Adversary and cooperationist Institutions for conflict resolution in public policymaking. Journal of Policy Analysis and Management, 11, 178-206.

Kim, O., \& Walker, M. (1984). The free rider problem: Experimental evidence. Public Choice, 43, 3-24.

Kirchgässner, G., Feld, L. P., \& Savioz, M. R. (1999). Die direkte Demokratie: Modern, erfolgreich, entwicklungs - und exportfähig. Helbing and Lichtenhahn/ Vahlen/ Beck, Basel et al.

Kolm, S.C. (1973). A note on optimum tax evasion. Journal of Public Economics, 2, 265270. 
Kramer, R. M., \& Tyler, T. R. (Eds.). (1995). Trust in Organizations: Frontiers of Theory and Research. Thousand Oakes: Sage Publishers.

Levi, M. (1988). Of Rule and Revenue. Berkeley: University of California Press.

Lewis, A. (1982). The Psychology of Taxation. Oxford: Blackwell.

Mansbridge, J. (1994). Public spirit in political systems. In H. Aaron, T. Mann, \& T. Taylor (Eds), Values and Public Policy (pp. 146-172). Washington: Brookings.

Osterloh, M., \& Frey, B. S. (2000). Motivation, knowledge transfer and organizational forms. Forthcoming in: Organization Science.

Pommerehne, W. W. (1985). Was wissen wir eigentlich über Steuerhinterziehung? Rivista Internazionale di Scienze Economiche e Commerciali, 32, 1155-1186.

Pommerehne, W. W., \& Frey, B. S. (1992). The effects of tax administration on tax morale. Unpublished Manuscript, University of Zurich.

Pommerehne, W. W., \& Weck-Hannemann, H. (1996). Tax rates, tax administration and income tax evasion in Switzerland. Public Choice, 88, 161-170.

Pozo, S. (Ed.). (1996). Exploring the Underground Economy: Studies of Illegal and Unreported Activity. Kalamazaro: Upjohn.

Putnam, R. (1993). Making Democracy Work: Civic Traditions in Modern Italy. Princeton: Princeton University Press.

Pyle, D. J. (1990). The economics of taxpayer compliance. Journal of Economic Surveys, 5, 163-198. 
Robinson, S. L., Kratz, M. S., \& Rousseau, D. M. (1994). Changing obligations and the psychological contract: A longitudinal study. Academy of Management Journal, 37, 137152.

Rousseau, D. M., \& McLean Parks, J. (1993). The Contracts of Individuals and Organizations, Research in Organizational Behavior, 15, 1-43.

Roth J. A., Scholz, J. T., \& Witte, A. D. (Eds.). (1989). Taxpayer Compliance: An Agenda for Research. Philadelphia: University of Pennsylvania Press.

Schein, E. (1965). Organization Psychology. Englewood Cliffs: Prentice-Hall.

Schneider F., \& Enste, D. (2000). Shadow Economies: Size, Causes, Consequences. Journal of Economic Literature, 38, 77-114.

Schwartz, R. D., \& Orleans, S. (1967). On Legal Sanctions. University of Chicago Law Review, 34, 282-300.

Skinner, J., \& Slemrod, J. (1985). An Economic Perspective on Tax Evasion. National Tax Journal, 38, 345-353.

Slemrod, J. (Ed.). (1992). Why People Pay Taxes: Tax Compliance and Enforcement. Ann Arbor: University of Michigan Press.

Spicer, M. W. (1988). The Effect of Tax Evasion on Tax Rates under Leviathan. National Tax Journal, 40, 625-28.

Spicer, M. W., \& Lundstedt, S. B. (1976). Understanding Tax Evasion. Public Finance, 31, 295-305.

Srinivasan, T. N. (1973). Tax Evasion: A Model. Journal of Public Economics, 2, 339346. 
Stutzer, A. (1999). Demokratieindizes für die Kantone der Schweiz. Working Paper No. 23. University of Zurich: Institute for Empirical Research in Economics.

Sunstein, C. R. (1990). Political Self-Interest in Constitutional Law. In J. Mansbridge (Ed.), Beyond Self-Interest (pp. 209-223). Chicago and London: Chicago University Press.

Tanzi, V. (1982). The Underground Economy in the United States and Abroad. Massachusetts: Lexington.

Taylor, M. (1987). The Possibility of Cooperation. Cambridge: Cambridge University Press.

Williamson, O. E. (1985). The Economic Institutions of Capitalism. New York: Free Press. Wilson, J. Q. (1993). The Moral Sense. New York: Free Press.

Witte, A. D., \& Woodbury, D. F. (1985). The Effect of Tax Laws and Tax Administration on Tax Compliance: The Case of the U.S. Individual Income Tax. National Tax Journal, $38,1-13$.

Yitzhaki, S. (1974). A Note on Income Tax Evasion: A Theoretical Analysis. Journal of Public Economics, 3, 201-202. 


\section{THE CENTRE FOR TAX SYSTEM INTEGRITY WORKING PAPERS}

No. 1. Braithwaite, V. \& Reinhart, M. The Taxpayers' Charter: Does the Australian Taxation Office comply and who benefits? December 2000.

No. 2. Braithwaite, V. The Community Hopes, Fears and Actions Survey: Goals and Measures. March 2001.

No. 3. Braithwaite, V., Reinhart, M., Mearns, M. \& Graham, R. Preliminary findings from the Community Hopes, Fears and Actions Survey. April 2001.

No. 4. Mearns, M., \& Braithwaite, V. The Community Hopes, Fears and Actions Survey: Survey method, sample representativeness and data quality. April 2001.

No. 5. Sakurai, Y., \& Braithwaite, V. Taxpayers' perceptions of the ideal tax adviser: Playing safe or saving dollars? May 2001.

No. 6. Wenzel, M. The impact of outcome orientation and justice concerns on tax compliance: The role of taxpayers' identity. June 2001.

No. 7. Wenzel, M. Misperceptions of social norms about tax compliance (1): A prestudy. June 2001.

No. 8. Wenzel, M. Misperceptions of social norms about tax compliance (2): A field-experiment. June 2001.

No. 9. Taylor, N. Taxpayers who complain about paying tax: What differentiates those who complain from those who don't? June 2001.

No. 10. Wenzel, M. Principles of procedural fairness in reminder letters and awareness of entitlements: A prestudy. June 2001.

No. 11. Taylor, N. \& Wenzel, M. The effects of different letter styles on reported rental income and rental deductions: An experimental approach. July 2001.

No. 12. Williams, R. Prosecuting non-lodgers: To persuade or punish? July 2001.

No. 13. Braithwaite, V. Tensions between the citizen taxpaying role and compliance practices. Forthcoming.

No. 14. Taylor, N. Understanding taxpayer attitudes through understanding taxpayer identities. July 2001. 
No. 15. Shover, N., Job, J. \& Carroll, A. Organisational capacity for responsive regulation. August 2001.

No. 16. Tyler, T. R. Trust and law-abidingness: A proactive model of social regulation. August 2001.

No. 17. Genser, B. Corporate income taxation in the European Union: Current state and perspectives. August 2001.

No. 18. McBarnet, D. When compliance is not the solution but the problem: From changes in law to changes in attitude. August 2001.

No. 19. Schneider, F., Braithwaite, V. \& Reinhart, M. Individual behaviour in Australia's shadow economy: Facts, empirical findings and some mysteries. September 2001.

No. 20. Taylor, N. \& Wenzel, M. Comparing rental income and rental deductions for electronic versus paper lodgers: A follow-up investigation. November 2001.

No. 21. Braithwaite, J. Through the eyes of the advisers: A fresh look at tax compliance of high wealth individuals. September 2001.

No. 22. Braithwaite, J., Pittelkow, Y. \& Williams, R. Tax Compliance by the very wealthy: Red flags of risk. September 2001.

No. 23. Braithwaite, J. \& Williams, R. Meta risk management and tax system integrity. October 2001.

No. 24. Braithwaite, J. \& Wirth, A. Towards a framework for large business tax compliance. November 2001.

No. 25. Murphy, K. \& Sakurai, Y. Aggressive Tax Planning: Differentiating those playing the game from those who don't. October 2001.

No. 26. Morgan, S. \& Murphy, K. The 'Other Nation'? Understanding rural taxpayers' attitudes towards the Australian tax system. Forthcoming.

No. 27. Ahmed, E. \& Sakurai, Y. Small business individuals: What do we know and what do we need to know? Forthcoming.

No. 28. Hobson, K. Championing the compliance model: From common sense to common action? December 2001.

No. 29. Smart, M. The under thirty taxpayer: Different from the rest? Forthcoming.

No. 30. Job, J. \& Honaker, D. Short-term experience with responsive regulation in the Australian Taxation Office. May 2002. 
No. 31. Frey, B. A constitution for knaves crowds out civic virtues. June 2002.

No. 32. Feld, L. \& Frey, B. Trust breeds trust: How taxpayers are treated. June 2002. 